INTERNATIONAL TRADE POLICY

From Tariffs to the New Protectionism 


\title{
International Trade Policy
}

From Tariffs to the New Protectionism

\author{
David Greenaway \\ The University College at Buckingham
}

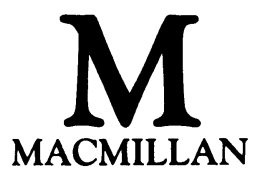


All rights reserved. No reproduction, copy or transmission of this publication may be made without written permission.

No paragraph of this publication may be reproduced, copied or transmitted save with written permission or in accordance with the provisions of the Copyright, Designs and Patents Act 1988, or under the terms of any licence permitting limited copying issued by the Copyright Licensing Agency, 90 Tottenham Court Road, London W1P 9HE.

Any person who does any unauthorised act in relation to this publication may be liable to criminal prosecution and civil claims for damages.

First published 1983 by

THE MACMILLAN PRESS LTD

Houndmills, Basingstoke, Hampshire RG21 2XS

and London

Companies and representatives

throughout the world

Published in the USA 1983 by

St. Martin's Press, New York

under the title 'Trade Policy and the New Protectionism'

ISBN 978-0-333-31253-7

ISBN 978-1-349-17024-1 (eBook)

DOI 10.1007/978-1-349-17024-1

A catalogue record for this book is available

from the British Library.

$\begin{array}{rrccrrrrr}10 & 9 & 8 & 7 & 6 & 5 & 4 & 3 & 2 \\ 03 & 02 & 01 & 00 & 99 & 98 & 97 & 96 & 95\end{array}$

The paperback edition of this book is sold subject to the condition that is shall not, by way of trade or otherwise, be lent, re-sold, hired out, or otherwise circulated without the publisher's prior consent in any form of binding or cover other than that in which it is published and without a similar condition including this condition being imposed on the subsequent purchaser. 
To my Mother and Father 


\section{Contents}

PREFACE $\quad x i$

LIST OF TABLES Xiii

INTRODUCTION 1

PART I Causes and Consequences of International Exchange and Specialisation

1 AN OVERVIEW OF THE DETERMINANTS OF EXCHANGE AND SPECIALISATION 9

Preconditions for exchange 9

Supply-side determinants of exchange $\quad 10$

Demand-side determinants of exchange 23

Postscript: inter-industry trade and intra-industry trade 29

2 WELFARE IMPLICATIONS OF SPECIALISATION AND EXCHANGE 32

Inter-industry exchange $\quad 32$

Intra-industry exchange $\quad 37$

PART II The Old Protectionism: Aspects of Tariff Interventions 43

3 ECONOMIC EFFECTS OF TARIFF INTERVENTIONS 45 Forms of tariff intervention $\quad 45$

Economic effects of tariff imposition 46

Trade restriction and the theory of optimal interventions $\quad 52$

Reliance on tariffs for commercial policy 59

4 NOMINAL AND EFFECTIVE PROTECTION 65

The concept of effective protection $\quad 65$

Elaborations of the simple effective protection concept $\quad 70$

Measurement of effective protection $\quad 73$

Empirical results $\quad 76$

$\begin{array}{ll}\text { Effective protection and trade policy } & 79\end{array}$ 
5 DISMANTLING THE OLD PROTECTIONISM: TARIFF LIBERALISATION AND GATT

The origins of organised liberalisation $\quad 82$

GATT: structure and functions $\quad 84$

Tariff liberalisation under GATT $\quad 89$

Tariff liberalisation outside GATT $\quad 97$

6 MEASURING THE EFFECT OF TARIFF BARRIERS 100

Identifying the effects of tariff liberalisation 100

Estimating the static consequences of tariff liberalisation 103

Ex ante estimation 103

Problems with ex ante estimation 108

Ex post estimation $\quad 113$

Empirical studies of the effects of tariff barriers 115

PART III The New Protectionism: Aspects of Non-Tariff Interventions

7 THE ECONOMIC EFFECTS OF NON-TARIFF INTERVENTIONS

Direct quantitative non-tariff barriers 131

Fiscal non-tariff interventions 143

Administrative and technical barriers 147

$\begin{array}{ll}\text { Non-tariff barriers and effective protection } & 149\end{array}$

8 THE EMERGENCE OF THE NEW PROTECTIONISM 152

Dynamic comparative advantage and structural

unemployment

$\begin{array}{ll}\text { The new protectionism } & 160\end{array}$

9 THE EXTENT AND CONSEQUENCES OF THE NEW PROTECTIONISM

The pattern of non-tariff interventions 164

The restrictiveness of non-tariff barriers 171

Non-tariff protection in the textile and clothing sectors $\quad 176$

PART IV Adjustment to Trade Expansion

10 THE ECONOMICS OF ADJUSTMENT 185

Trade-related adjustment pressures $\quad 185$

Adjustment and the new protectionism 189

Responses to adjustment difficulties 191

Instruments of adjustment policy 197 
11 TRADE POLICY AND EMPLOYMENT 201 Identifying employment changes: methodology 201 Empirical analyses of the employment consequences of trade expansion/contraction

12 TRADE POLICY AND ADJUSTMENT

Trade policy and defensive adjustment

$\begin{array}{ll}\text { END-NOTES } & 220\end{array}$

$\begin{array}{ll}\text { REFERENCES } & 227\end{array}$

$\begin{array}{ll}\text { AUTHOR INDEX } & 236\end{array}$

$\begin{array}{ll}\text { SUBJECT INDEX } & 238\end{array}$ 


\section{Preface}

International Trade Policy grew out of the author's experiences in teaching a final-year undergraduate course in International Economics at the University College at Buckingham; a substantial part of this course is devoted to trade policy, in particular the 'new protectionism'.

The text is written principally for the consumption of undergraduates following courses in International Economics and International Trade. It therefore presumes familiarity with the principles of basic microeconomics and (although mathematical exposition is used sparingly) basic mathematics.

In this text an attempt is made to review and, where possible, synthesise theoretical and empirical aspects of tariff and non-tariff interventions, while emphasising the institutional framework within which tariffs have been gradually replaced by non-tariff instruments as the principal tools of commercial policy. There are therefore chapters which deal with the economic effects of tariff and non-tariff instruments as well as chapters outlining the methodological difficulties of quantifying their effects. In addition, there are chapters dealing with the emergence and operation of GATT and recent threats to the credibility of that organisation. Finally, for completeness, there are chapters which identify the forces which result in international specialisation and exchange, and adjustment difficulties which may be associated with the process.

Deciding how best to organise this material proved a little difficult. The obvious way would perhaps have been to group together theory chapters, empirical chapters and institutional chapters. From the reader's point of view, such an approach would have had advantages in facilitating immediate comparison between tariff and non-tariff instruments. Instead, however, the material has been ordered in such a way that theoretical, empirical and institutional aspects of tariff barriers are grouped together, and similarly with non-tariff barriers. It was felt that not only did this provide the opportunity for the reader to be presented with a fairly complete and integrated review of economic aspects of each type of instrument, but also that it lent some loose chronological ordering to the material.

The text does not cover every aspect of commercial policy, the most obvious exclusion being a consideration of customs-union theory. 
The exclusion clauses in the GATT articles dealing with customs unions have undoubtedly influenced economic integration in Western Europe quite significantly. We simply allude to such issues en passant, however, in part to give due emphasis to the new protectionism, in part because economic integration is an issue which is already given adequate coverage in the textbook literature.

A great many people have assisted, whether knowingly or otherwise, in the preparation of this volume. Chris Milner (University of Loughborough) read the entire draft manuscript and made a great many helpful suggestions. In addition, one or more chapters were perused by Hugh Corbet (Trade Policy Research Centre), Andrew Mason (University College at Buckingham), David Sapsford (University of East Anglia) and Ron Shone (University of Stirling). All of the chapters in question underwent improvement as a result of comments from these individuals. Some of the policy chapters were prepared while I was a Visiting Scholar at the Graduate Institute of International Studies in Geneva and these benefited from conversations with Gerard Curzon. Despite such extensive advice, errors of commission and omission no doubt remain for which I alone am, of course, responsible.

The draft chapters and subsequent revisions were conscientiously and expeditiously typed by Linda Waterman, who as well as compiling the manuscript drew my attention to many grammatical errors.

Finally, my wife Susan and my children Stuart and Daniel deserve my warmest thanks for their encouragement and forbearance. Much of the time expended on this text should perhaps have been leisure time, a substantial share in which would have been theirs. 


\section{List of Tables}

I.1 Networks of world trade, 1955, 1968 and 1976

I.2 Indices of 'openness' 3

I.3 Structure of merchandise exports 4

4.1 Nominal rates of tariff on inputs and outputs, and effective rates

4.2 Rank correlation coefficients between nominal and effective rates of protection

4.3 Average nominal and effective rates of protection by industrial category in the United Kingdom, 1968

4.4 Nominal and effective rates of protection in the United Kingdom, 1968

5.1 GATT articles of agreement

5.2 Tokyo Round tariff changes

5.3 Tokyo Round tariff changes on industrial products: country breakdown

6.1 Welfare effects of tariff imposition in the United Kingdom

6.2 Static welfare effects of various multilateral tariff cuts

6.3 Static welfare gains of alternative tariff-cutting formulae

7.1 Non-tariff instruments of intervention

8.1 Commodity composition and growth of merchandise exports for selected NICs

8.2 OECD imports of manufactures from newly industrialising countries

8.3 Contribution of 'labour-absorbing' and 'labour-shedding' industries to annual average growth rates of manufacturing employment

8.4 Actions to restrict imports, 1971-7

9.1 Frequency of non-tariff barriers by commodity group: imports into OECD countries, 1970

9.2 Managed trade by country

9.3 Commodities in which importers controlled more than 30 per cent of trade in 1979

9.4 Shares of managed trade in world trade flows, 1970-7

9.5 Effects of changes in demand, productivity and trade balance on apparel employment in seven leading industrial countries, 1970-6

11.1 Employment effects of a 50 per cent tariff cut in the USA 207 